DNIVRSIIE PARE
$\mathrm{D}$

I $\underset{\text { A }}{\mathrm{L}} \mathrm{L}$

UMR 225 IRD - Paris-Dauphine

DOCUMENT DE TRAVAIL

DT/2013-11

\title{
Migrants' Home Town Associations and Local Development in Mali
}

\section{Lisa CHAUVET}

Flore GUBERT

Marion MERCIER

Sandrine MESPLE-SOMPS

UMR DIAL 225

Place du Maréchal de Lattre de Tassigny 75775• Paris Cedex 16 •Tél. (33) 0144054542 • Fax (33) 0144054545 • 4, rue d'Enghien• 75010 Paris • Tél. (33) $0153241450 \bullet$ Fax (33) 0153241451

E-mail : dial@dial.prd.fr $\bullet$ Site : $\underline{\text { www.dial.prd.fr }}$ 


\title{
MIGRANTS' HOME TOWN ASSOCIATIONS AND LOCAL DEVELOPMENT IN MALI ${ }^{1}$
}

\author{
Lisa Chauvet \\ IRD, UMR DIAL, 75010 Paris \\ PSL, Université Paris-Dauphine, \\ LEDa, UMR DIAL, 75016 Paris, France \\ chauvet@dial.prd.fr \\ Marion Mercier \\ IRD, UMR DIAL, 75010 Paris \\ Paris School of Economics \\ mercier@dial.prd.fr
}

\author{
Flore Gubert \\ IRD, UMR DIAL, 75010 Paris \\ Paris School of Economics \\ PSL, Université Paris-Dauphine, \\ LEDa, UMR DIAL, 75016 Paris, France \\ gubert@dial.prd.fr \\ Sandrine Mesplé-Somps \\ IRD, UMR DIAL, 75010 Paris \\ PSL, Université Paris-Dauphine, \\ LEDa, UMR DIAL, 75016 Paris, France \\ mesple@dial.prd.fr
}

\section{Document de travail UMR DIAL}

Octobre 2013

\begin{abstract}
This paper explores the impact of Malian migrants' Home Town Associations (HTAs) located in France on the provision of local public goods in Mali. To this end, we compute an original dataset on all the HTAs that have been created by Malian migrants in France since 1981 and geo-localize their interventions on the Malian territory. Thanks to four waves of Malian census, we also build a panel dataset on the provision of a range of public goods in all Malian villages over the 1976-2009 period. These two sources of data allow us to implement a difference-in-differences strategy, and to compare villages with and without an HTA, before and after HTAs developed their activity in Mali. We find that Malian HTAs have significantly contributed to improve the provision of schools, health centers and water amenities over the 1987-2009 period. When looking at the timing of the treatment, we observe that the difference between treated and control villages in terms of water amenities is mainly driven by the second period of observation (1998-2009), while schools and health centers exhibit significant differences during the whole period.
\end{abstract}

Key words: Local public goods, Migration, Mali.

\section{Résumé}

Nous analysons l'impact des associations de migrants (AM) de Maliens vivant en France sur la disponibilité en biens publics au Mali. Pour ce faire, nous avons constitué une base originale de données qui recense l'ensemble des AM maliennes enregistrées au Journal Officiel français depuis 1981 et qui géo-référence leurs lieux d'intervention. Cette base est couplée avec quatre recensements exhaustifs qui permettent de connaître la disponibilité en biens publics de chaque village malien de 1976 à 2009. En mettant en œuvre une estimation en double différences, nous montrons que les AM maliennes ont significativement contribué à l'augmentation du nombre d'écoles, de centres de santé et d'adduction d'eau sur la période 1987-2009. Plus précisément, on observe que la différence entre le groupe de villages traités et le groupe de contrôle concernant l'adduction en eau est dû à des investissements menés durant la seconde période (1998-2009) tandis que les financements des AM concernant les écoles et les centres de santé ont eu lieu tout au long de la période 1987-2009.

Mots Clés : $\quad$ biens publics locaux, migration, Mali.

JEL Code: F22, H41, H75, O55.

This research has been supported by the French Ministry of Foreign Affairs, the AIRD ("FSP Mali contemporain"), the programme "Emergence" from Paris municipality, the French National Research Agency and the European 7th PCRD (program NOPOOR). We thank Margharita Comola, Sylvie Lambert, Katharina Michaelowa, Jean-Noël Senne and participants to the University of Zurich seminar, the CSAE conference, NORFACE conference, the 12th journées LouisAndré Gérard-Varet and DIAL conference for helpful discussions and comments. We also thank Claire Bernard, Mahamadou Dangnoko, Anda David and Nelly Rakoto-Tiana for their help with data collection. Finally, we thank the Malian statistical office (INSTAT), particulary Assa Doumbia for providing the census data. 


\section{Introduction}

Recent years have witnessed a growing interest of scholars, development practitioners and international organizations for the relationship between migration and development. In particular, academic research has strongly focused on the impact of remittances on origin countries, notably on aggregate development outcomes such as poverty and growth and on recipient households' behavior. External remittances have become indeed an increasingly substantial source of financial flows for developing countries, and have outstripped private capital flows and official development aid in many of them. In 2011, remittances were the second largest source of external finance to developing countries as a whole (370 billion dollars) behind foreign direct investment (around 500 billion dollars). They were nearly three times larger than official development assistance (around 140 billion dollars) (Ratha and Silwal (2012)).

In addition to sending remittances to their family, migrants frequently contribute to the development of their village of origin by sending collective transfers through Home Town Associations (HTAs). HTAs are voluntary clubs located in immigrants' host societies made up of migrants from the same locality of origin. Their aim is to fund local development projects, and as such they received an increased attention from the development community which considers them as potential actors in the process of leveraging funds for investment and development in resource-poor communities of origin. There are indeed good reasons to be optimistic about the role of HTAs in development. In a context of weak states with low fiscal capacity, HTAs and collective remittances may complement scarce public resources and relieve binding budget constraints. Thus, the population of the locality of origin where the HTAs intervene may end up better off.

Yet, the question of HTAs' real impact on local development is not that straightforward. First, collective remittances may crowd out public finance. Indeed, by relaxing important bottlenecks, they may create a disincentive for the state and local governments to intervene and result in lower public spending (Grabel (2008)). In other words, HTAs 
activity may allow local governments to extricate themselves from their traditional responsibilities, leaving the targeted localities worse off in terms of public goods. Second, HTAs may not be as effective as public actors in terms of development objectives. Indeed, the impact of HTAs' activity depends on how projects are conceived and selected and on how transparent and inclusive are decision-making processes. When projects are designed by HTAs' members from abroad with little or no input from their potential beneficiaries, they may be ill-conceived, may not meet the needs of home communities, and may thus be quickly abandoned. Third, when the migration process is selective and mainly involves certain groups, HTAs' projects may serve private agendas rather than addressing larger community needs. Their benefits may thus be narrowly distributed and aggravate social cleavages in the community. In this scenario, HTAs may contribute to erode social cohesion within the local communities, thereby altering their capacity to agree upon and implement collective action, which ultimately has detrimental effects on sustained local development.

In the case of Mali, a few small-scale case studies focusing on the Kayes area, in the Western part of the country, describe migrants' HTAs as a substantial source of funding and document the number and type of development projects they have financed. ${ }^{1}$ However, the contribution of HTAs at the national level has never been systematically investigated, and there is no quantitative evidence on whether their activity makes the villages of origin better off in terms of local public goods than the villages with no HTA. This lack of evidence on the net impact of HTAs on local development is not restricted to Mali, and the literature provides very little quantitative evidence on collective remittances. $^{2}$ One major exception is the work of Beauchemin and Schoumaker (2009) on

\footnotetext{
${ }^{1}$ The pioneering research on this topic has been written in the 1990s, see for instance Quiminal (1991) and Daum (1998). Gauvrit and Le Bahers (2004) make an inventory of development projects financed by HTAs in 51 Malian localities in the Kayes region, whereas Charef and Gonin (2005) undertake several case studies at the locality level, all of them in the Kayes region.

${ }^{2}$ In the case of Mexico, the literature provides some insights on collective remittances through the analysis of a specific program called Tres por Uno (3x1). This program consists in supporting HTAs' activity in the development of origin communities by providing complementary funding through municipal, state and federal contributions. Aparicio and Meseguer (2012) find for e.g. that high-migration municipalities are more likely to participate to the program, but that, at similar levels of migration, poorer localities tend to benefit less from it. They also find a political bias in the allocation of public
} 
Burkina Faso. The authors exploit retrospective data covering the 1960-2002 period on a sample of 600 settlements and use event-history models to test whether the existence of a migrant association ${ }^{3}$ has an influence on the provision of public services, on agricultural modernization and on the availability of infrastructures. They find a positive and significant effect of HTAs on the provision of social services and roads, with some differences in magnitude from one decade to the other.

Strong data limitations explain this lack of quantitative assessment. The first phase of this research thus started with a long data collection process. We computed an original dataset that provides an exhaustive list of the HTAs created by Malian migrants in France. For each HTA, we have been able to find its date of creation, as well as the name of the locality where it intervenes in Mali. Thanks to the four waves of census (Recensement Général de la Population et de l'Habitat) conducted by the Malian Office of statistics for the years 1976, 1987, 1998 and 2009, we then built a panel dataset of all Malian villages and their stock of infrastructures at those four dates. Retrospective and exhaustive data on local public goods over such a long period are rare in Africa. We then combined our two datasets in order to compare the provision of public goods before and after the intervention of HTAs in villages with and without an HTA, through a difference-in-differences approach. Overall, we find that villages targeted by an HTA are better off in terms of public good provision. The impact varies depending on the type of public good and on the timing of the treatment. We then test the robustness of our results against the possibility of an endogenous selection into the treatment.

The rest of the paper is organized as follows. Section 2 documents the emergence and development of HTAs in Mali. The data and descriptive statistics are presented in Section 3. Section 4 describes our empirical strategy and provides benchmark results together with evidence that supports the parallel trend assumption underlying our difference-in-differences approach. In Section 5, we investigate potential selection issues goods financed by the 3x1 Program.

${ }^{3}$ Contrary to other West African countries such as Mali, most Burkinabé HTAs have been created by domestic migrants. 
which may bias our benchmark results. Section 6 concludes.

\section{The emergence and development of Malian mi- grants' HTAs}

Mali has a long-lasting history of migration, both within West Africa and with the rest of the world. Côte d'Ivoire is the main country of destination of Malian migrants, whereas France represents the most important destination among migrants who leave the African continent: in 2011, about 39\% Malian migrants were living in Côte d'Ivoire, 35\% in other African countries, $16 \%$ in France and $10 \%$ in the rest of the word. ${ }^{4}$

While the tradition of migration among the Malian population goes back to the precolonial period, the presence of the first Malian migrants in France is generally attributed to the considerable growth in sea-borne trade between West Africa and Europe prior to the First World War which led some Malians employed in the French merchant marine to settle in French harbor cities before moving to other places including Paris (Manchuelle (1997)). However, the bulk of migration from Mali to France occurred during the 1960s and 1970s. At that period, migration flows were mainly composed of individuals coming from the Kayes area, located in the Western part of the country, and belonging to the Soninke ethnic group. While migration to France has evolved and now includes individuals from other regions and ethnic backgrounds, the Kayes area remains the main region of origin of Malian migrants: 25\% of the migrants who have settled abroad, and more than a half of those living in France, originate from this region.

The rapid growth of the Malian community in France since 1960 has translated into increasing flows of remittances directly sent by the migrants to their families. It has also resulted in the spontaneous emergence and development of Home-Town Associations (HTAs) constituted of migrants originating from the same community in Mali. ${ }^{5}$

\footnotetext{
${ }^{4}$ Figure computed by the authors using data from the EMOP Enquete Modulaire et permanente auprès des Ménages representative survey, INSTAT Mali, 2011.

${ }^{5}$ The creation of HTAs is not exclusively undertaken by Malian migrants in France. According to the
} 
As underlined by the anthropological literature (see, e.g., Quiminal (1991), Daum (1995)), the earlier HTAs, the so-called "Caisses villageoises" were created for the specific purpose of helping their fellow migrants with any financial problem they might encounter in the host country. They were thus primarily concerned with settlement in France. It is only in the 1980s that HTAs started expanding their scope of operations to address concerns not only in the country of destination but also in Mali. While their actions were initially confined to prestigious projects such as the construction of mosques, they gradually covered every aspect of daily life in the villages with development projects ranging from hydraulics to healthcare and from basic education to cultural exchanges. French public policies did play a role in this trajectory as foreigners were not allowed to gather in associations, and gained this right when a left-wingist government came to power in 1981. This allowed HTAs to be officially registered in France, a prerequisite to collect membership fees and organize fundraising. According to Daum (1998), 95\% of all the HTAs which were existing in 1992 were officially registered.

Collecting reliable data on associations is an exceedingly difficult task in most immigration countries considering the small size and informality of most HTAs. In the case of France, however, the fact that most HTAs are officially registered has facilitated the data collection process (see Section 3 below). According to Daum (1998), there were 143 Malian HTAs registered in France in 1992, a number that had increased up to 421 by 2009 according to our own estimates (Bernard et al. (2013)).

2012 edition of the EMOP survey, $61 \%$ of the HTAs recorded in the sample villages have been created by migrants living in countries other than France, Their distribution by region reflects international migration patterns: they are indeed much less concentrated in the Kayes region than HTAs hosted in France: only $21 \%$ intervene in this region against respectively $27 \%$ and $26 \%$ in the regions of Mopti and Koulikoro. Many HTAs have also been created by internal migrants. The EMOP survey enumerated no less than 526 such HTAs in its 2012 edition. Internal HTAs and HTAs located in other destination countries have lower resources and financial leverage than those hosted in France, which justifies our focus on the latter. 


\section{Data}

We mobilize two sources of data to explore the link between migrants' HTAs and the provision of local public goods in the Malian villages over the 1987-2009 period. The first one is an original and exhaustive census of the Malian HTAs in France. The second is a panel of Malian villages that we compute using the 1976, 1987, 1998 and 2009 Malian Population Censuses (Recensement Général de la Population et de l'Habitat, INSTAT).

\subsection{Home Town Associations}

We collected an exhaustive original dataset on Malian migrants' HTAs in France. Identifying migrants' associations is generally tricky, as any non-profit association created in France (also called Association Loi 1901) can operate without being registered. However, registration becomes a prerequisite if a bank account is needed or if the association aims at collecting membership fees or arranging fundraising. Registration is made at the Préfecture or Sous-Préfecture of the district where the association is located. This simple registration procedure is followed by a declaration of the association's creation in the French Official Journal (Journal Officiel), a daily paper edited by the French government containing legal information, official notifications and detailed information concerning new associations, in particular their name and object.

Foreigners gained the right to gather in associations in France when the Socialist Party came to power in 1981. It took a few years, however, before the first Malian migrants' HTAs started declaring themselves. Before 1987 indeed, which constitutes the "baseline" year in our empirical analysis, only 13 HTAs had registered, 10 of them operating in the Kayes region. Of course, it is likely that some HTAs were functioning before 1981

without being registered. If this were true, this could bias our results by contaminating the control group. However, this bias is likely to be negligible as HTAs created in the 1970s and early 1980s were not actively involved in the development of the villages of origin. 
We used the archives of the French Journal Officiel to seek all the Malian HTAs declared in France. Concretely, we extracted from the Journal all the associations containing, in their name or declared purpose, either the word "Mali" or any of its derivatives in French, or the name of one of the 10,000 villages of Mali. The methodology of this data collection is further detailed in Bernard et al. (2013). We ended up with 421 Malian HTAs declared between 1981 and 2009 which aim is to channel funds for the development of small-scale areas (either villages or communes). We excluded from our census all the HTAs targeting entire regions (or even Mali as a whole), for not being able to precisely identify where they intervene.

Table 1 presents the distribution of the 421 HTAs created over the 1987-2009 period, by region. Column (1) provides totals, while columns (2), (3) and (4) provide sub-totals after disaggregating the sample according to the date of registration of each HTA.

Table 1: Number of Malian HTAs registered in France

\begin{tabular}{lcccc}
\hline \hline & $(1)$ & $(2)$ & $(3)$ & $(4)$ \\
& Total & Before 1987 & $1987-1998$ & $1998-2009$ \\
\hline Mali & 421 & 13 & 116 & 292 \\
\hline Kayes & 310 & 10 & 89 & 211 \\
Koulikoro & 44 & 1 & 11 & 32 \\
Sikasso & 10 & 0 & 2 & 8 \\
Ségou & 6 & 1 & 1 & 4 \\
Mopti & 41 & 0 & 11 & 30 \\
Tombouctou & 3 & 0 & 1 & 2 \\
Gao & 4 & 1 & 0 & 3 \\
Kidal & 3 & 0 & 1 & 2 \\
\hline \hline
\end{tabular}

The spatial distribution of HTAs clearly confirms the role of the Kayes area as the main source of Malian migrants to France: $73.5 \%$ of the Malian HTAs created in France before 2009 target a locality in Kayes. The remainder mainly concentrates on Koulikoro (10.5\%) and Mopti (9.5\%). Then come Sikasso (2.5\%) and Ségou (1.5\%). Less than 1\% of the HTAs targets each of the three remaining regions (Gao, 1\%, and Tombouctou and Kidal, $0.5 \%$ each).

As a last step, we associate to each village of Mali a dummy variable indicating 
whether this village is targeted by (at least) one HTA. ${ }^{6}$ This dummy is our treatment variable. We consider a village as treated in two cases: first, if it is directly targeted by a French HTA, and second, if the village is part of a commune which is targeted by a French $\mathrm{HTA}^{7}$.

This dataset allows us to distinguish between treated localities and their control counterparts, which have no HTA in France. To assess the differences between treated and control villages in terms of local public good provision, we focus on the sample of villages that we can track from 1987 to 2009. Indeed, the territorial composition of the country experienced transformations over the period, in particular driven by the huge growth of the Malian population and by internal migration patterns which led to the birth of new villages, or conversely to the aggregation of villages. Moreover, in 1998, the insecurity in the Northern part of the Malian territory linked to the Touareg rebellion prevented the national office of statistics to collect data in some areas of the regions of Gao and Kidal.

These restrictions make us end up with a sample of 8,606 villages out of the 10,629 Malian villages of the census of 2009. Among those 8,606 villages, 60 are further excluded from the analysis for being targeted by the 13 HTAs created between 1981 and 1987. Thus, 8,546 localities will be included in the estimations. 7,381 of them belong to the control group and 1,165 to the treated one. In the latter group, 495 had their first HTA created before 1998, and 670 afterwards. The distribution of treated and control villages by region is given by Table 2 .

One important drawback of these data comes from the fact that we do not have much information on HTAs' dissolution. In theory, any change made in the association should be published in the Journal Officiel. Declaring a dissolution, be it voluntary, legal or administrative, is a procedure as simple as notifying a creation, but in practice it is not compulsory and very few associations do it. When assessing the difference, in terms of local public good provision, between villages with and without HTA, we thus estimate a

\footnotetext{
${ }^{6}$ More precisely, the geographic unit of observation is the village in rural areas and the neighborhood in urban areas. In the rest of the paper, we will use the terms "villages" or "localities" indifferently to refer to rural villages and to urban neighborhoods.

${ }^{7}$ In average, each commune gathers on average 15 villages.
} 
lower bound given that some associations observed in our data potentially do not exist any more.

Table 2: Number of villages with and without HTA

\begin{tabular}{lccccc}
\hline \hline & $\begin{array}{c}(1) \\
\text { Localities }\end{array}$ & $\begin{array}{c}(2) \\
\text { Localities with } \\
\text { an HTA created } \\
\text { before } 1987\end{array}$ & $\begin{array}{c}\text { Localities with } \\
\text { an HTA created } \\
\text { between 1987 } \\
\text { and 1998 }\end{array}$ & $\begin{array}{c}\text { Localities with } \\
\text { an HTA created } \\
\text { after 1998 }\end{array}$ & $\begin{array}{c}\text { Localities } \\
\text { without HTA }\end{array}$ \\
\hline Mali & 8606 & 60 & 495 & 670 & 7381 \\
\hline Kayes & 1311 & 51 & 221 & 299 & 740 \\
Koulikoro & 1624 & 7 & 145 & 231 & 1241 \\
Sikasso & 1523 & 0 & 26 & 27 & 1470 \\
Ségou & 1801 & 1 & 1 & 4 & 1795 \\
Mopti & 1832 & 0 & 98 & 63 & 362 \\
Tombouctou & 395 & 0 & 4 & 17 & 102 \\
Gao & 120 & 1 & 0 & 0 & 0 \\
Kidal & 0 & 0 & 0 & & 29 \\
\hline \hline
\end{tabular}

\subsection{Local public goods}

Data on the Malian villages come from the four population censuses conducted by the Malian Office of statistics (INSTAT) in 1976, 1987, 1998 and 2009. These censuses provide information on the number and type of public goods at the level of the villages. ${ }^{8}$ Thanks to these data, we compute three indicators of local infrastructures for each Malian village that are strictly comparable between the years 1976, 1987, 1998 and 2009:

- $S C H O O L$ : Number of primary and secondary schools;

- HEALTH: Number of health centers;

- WATER: Number of public fountains.

Moreover, the 1998 and 2009 data provide disaggregated information on the type of available health equipments. This allows us to build five more indicators of health infrastructures for these two years:

\footnotetext{
${ }^{8}$ See footnote 6 for a more precise definition of the geographic unit of observation.
} 
- HOSP: Number of hospitals;

- CLINICS: Number of clinics;

- DISPENS: Number of dispensaries;

- MATER: Number of maternities;

- CSCOM: Number of community health centers ${ }^{9}$.

The Malian censuses of 1987, 1998 and 2009 also provide household-level data on housing conditions which we rely on to build three additional variables informing the type of access to water:

- HH_TAP: Share of households in the village using a tap as source of water;

- HH_WELL: Share of households in the village using a well or a drilling as source of water;

- HH_FOUNTAIN: Share of households in the village using a public fountain as source of water.

All three measures relate to alternative water supply amenities which differ from one another in terms of the initial investment they require and of the quality of the water they supply. Finally, the household-level data allow us to calculate the share of households in the village that are connected to the electrical grid, HH_ELEC.

Table 3 presents the means and standard deviations of the different public good measures within the treated and control groups, and the average differences between the two groups at each wave of the census (i.e. in 1976, 1987, 1998 and 2009). The number of schools, water amenities and health infrastructures experienced a sustained increase from 1976 to 2009, the pace of this increase being stronger after 1987. This is the case both for the treated and for the control groups. Between the years 1998 and 2009, for

\footnotetext{
${ }^{9}$ The CSCOM, Centres de santé communautaires, are community health centers which developed from the beginning of the nineties and centralize multiple health services in a single place. They are managed by community associations and usually gather a dispensary, a maternity and a pharmacy.
} 
which we have disaggregated data on health infrastructures, the number of dispensaries and maternities decreased in both groups while the number of CSCOM largely increased. This trend reflects the public willingness to develop these types of health centers from the beginning of the nineties. Turning to the alternative sources of water, the share of households using a tap increased a lot in both groups over the period. At the same time, the share of households using a well or a drilling remained roughly stable, while the share of households using a fountain first increased (between 1987 and 1998) and then decreased (between 1998 and 2009). Finally, in both groups, the share of households connected to the electrical grid experienced a growing trend over the period that accelerated between 1998 and 2009.

Turning to the average differences between the treated and control groups, it appears that treated villages were better endowed in terms of most public goods at the beginning of the period, and remained better endowed, though these differences are not systematically statistically significant. Regarding households' access to the different water sources and to electricity, we observe that the share of households using a tap increased between 1987 and 2009 in both groups, the treated localities starting from a slightly higher level. The share of households using a well or a drilling remained roughly stable over the period and within both groups. The share of households using a public fountain increased in both groups, the control group starting with a higher proportion in 1987 . Finally, the average share of households connected to electricity, though still very low, increased substantially in both samples (the treated group exhibiting a higher starting point).

In the rest of the paper, we will perform difference-in-differences estimations questioning the impact of HTAs on the provision of local public goods from 1987 to 2009, relying on a panel data set at the level of the Malian villages over the 1976-2009 period. 


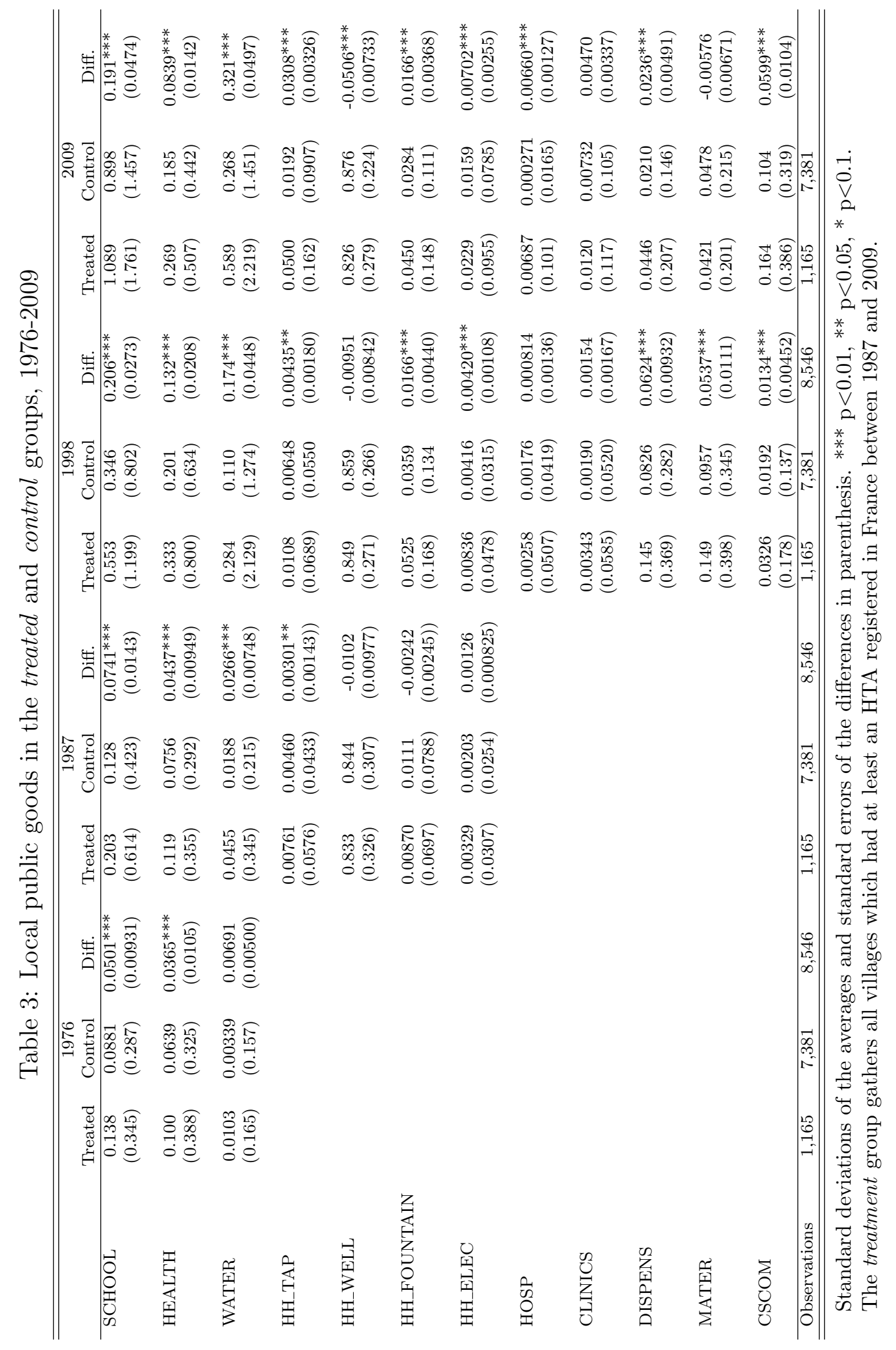




\subsection{Other observable characteristics}

The Malian censuses also provide individual-level data which allow us to compute the following village-level variables:

- Population: size of the population of the locality;

- Ethno-linguistic fragmentation: one minus the Herfindahl index computed relying on the share of each ethnic group (based on mother tongue);

- \% of labor force in the primary sector: share of the active population of the village working in the agricultural sector;

- Returnees France: share of the population of the village who has been living in France for more than six months (available only in 1998 and 2009);

- Emigration France: share of the population of the village currently living in France, only available in $2009 .{ }^{10}$

We also rely on the data of the Climatic Research Unit, University of East Anglia, to compute the average annual rainfall and average rainfall shocks experienced by the villages over the previous decade. We derive the latter variable by regressing, for each village, the level of yearly observed rainfalls on their lagged values and on a time trend, and by calculating the standard deviation of the predicted residuals of these estimations over ten years.

In Table 4, we present the means and standard deviations for the different observed characteristics of the treated and control villages, and the average differences between these two groups at each wave of the census. Table 4 shows that treated villages are, on average, larger than control villages, and have experienced a larger demographic growth since 1987. Treated villages are also more ethnically fragmented than control villages, even though the difference between the two groups has decreased since 1987. On average, annual rainfalls are significantly lower in the treated villages than in the control villages.

\footnotetext{
${ }^{10}$ The census questionnaire only identifies migrants who left Mali less than 5 years ago.
} 


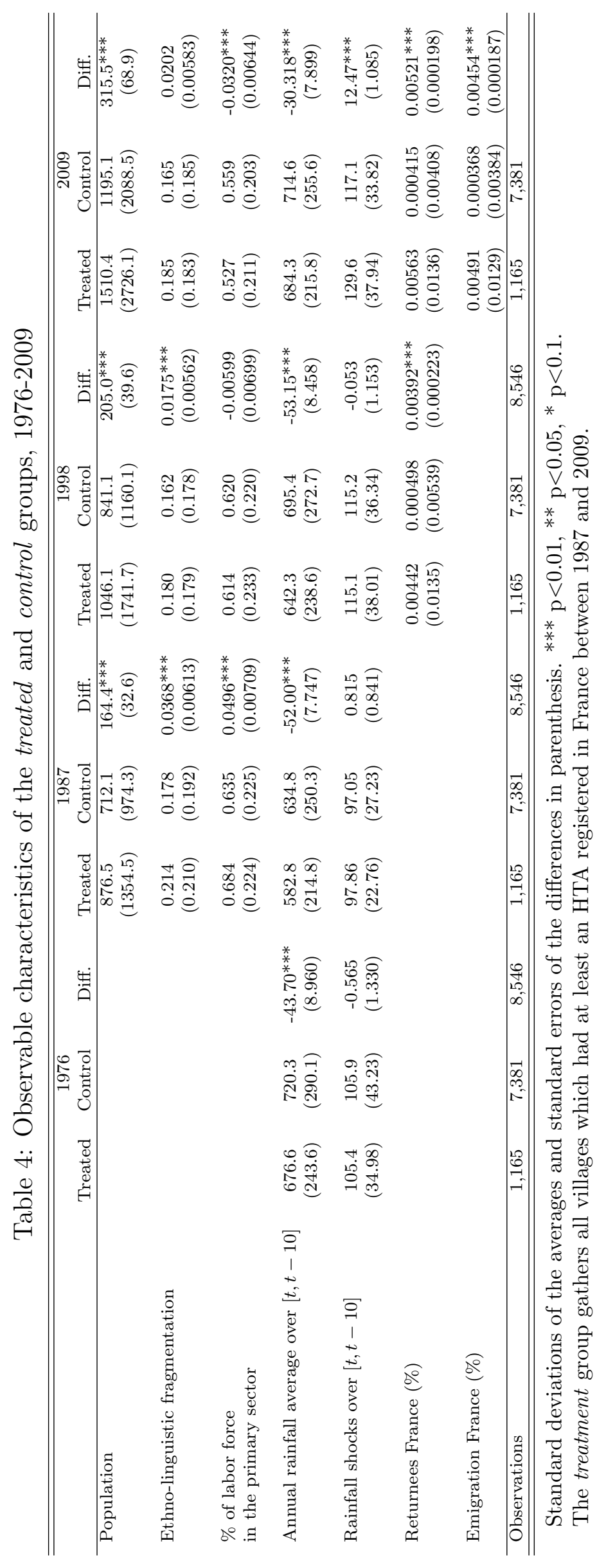


The volatility of rainfalls was not significantly higher in treated villages, but became so over the last decade, 1999-2009. Finally, treated and control villages largely differ in terms of migration intensity, as reflected by the percentage of return and current migrants from/in France. Those descriptive statistics are in line with the fact that HTAs are created where a sufficient number of migrants and return migrants are gathered, and mainly in the North Western part of Mali where rainfall are lower than in the South.

\section{Empirical strategy and benchmark results}

In what follows, we consider the presence of one or several HTAs in a given village as a treatment variable. We rely on a difference-in-differences approach and proceed in three steps: we first compare changes in local public good provision between the treated and the control villages between 1987 and 2009. As suggested by Table 2 indeed, very few HTAs were created (and registered) before 1987. We thus exclude from our sample the 60 villages which had an HTA before 1987, and consider the 1987 and 2009 Population censuses as our baseline and endline surveys respectively. We then investigate the potential heterogeneity of the treatment effect across subperiods of time. Indeed, we observe the provision of public goods in the Malian villages in 1976, 1987, 1998 and 2009. We can match these data emanating from the four waves of the census with the dates of HTAs' registration in France. We estimate separately the impact of earlier HTAs (created before 1998), both over the first and over the second decade of treatment (1987-1998 and 1998-2009), and the impact of more recent HTAs (created after 1998) over the 1998-2009 period. We finally question the identifying assumption of the difference-in-differences approach which requires that localities with HTAs would have followed a trend in local public good provision similar to that observed in their non-treated counterparts, had they not had any HTA. We provide evidence on this parallel trend assumption by testing whether treated and control villages were already experiencing different trends in terms of public good provision before the treatment occurrence (i.e. between 1976 and 1987). 
As a first step, we estimate the following econometric model:

$$
L P G_{i, t}=\alpha_{0}+\delta_{t}+\nu_{i}+\alpha_{1} D_{i, t}+\theta_{j} * \delta_{t}+\epsilon_{i, t}
$$

where $L P G_{i, t}$ is the level of public goods in locality $i$ at time $t, \delta_{t}$ is a time fixed-effect, $\nu_{i}$ is a village fixed-effect and $D_{i, t}$ is a dummy equal to 1 if village $i$ has at least one HTA during the considered period. The village fixed-effects $\nu_{i}$ capture all the time-invariant characteristics of the villages affecting the level of public goods. $\theta_{j} * \delta_{t}$ are commune dummies interacted with time dummies. These variables account for unobservable timevariant characteristics at the level of the communes. By introducing them, we control for other confounding factors, at the commune level, that might explain the contrasted evolutions observed between treated and control villages over the 1987-2009 period. The allocation of central resources to communes could be for e.g. systematically biased in favor of (or against) migrant-prone areas and lead us to over-(or under-)estimate the impact of the treatment. Finally, $\epsilon_{i, t}$ is an idiosyncratic error term.

Tables 5 and 6 provide regression results of Equation 1 using as dependent variables the provision of various types of local public goods, on different time spans. In the second panel of each Table, we question the parallel trend assumption by investigating the pretreatment periods. In column (1a) we compare changes in local public good provision between the treated and the control villages between 1987 and 2009, without introducing the commune $\mathrm{x}$ time dummies. Column (1b) presents our preferred specification, where these variables are included.

The evolution of local public good provision over the 1987-2009 period is found to be significantly different between villages with and without an HTA. The estimated difference is overall stronger when commune $\mathrm{x}$ time dummies are controlled for - with the exception of the share of households with access to electricity. Using column (1b) of Tables 5 and 6 as benchmark, we find that on average, villages which benefit from the support of at least one HTA tend to have more schools, public fountains and health amenities than control 
villages. The size of the coefficients suggests that the number of public fountains has increased by one more unit in average, and the number of schools by a bit less than one unit more in average, in villages targeted by at least one HTA between 1987 and 2009 . Note that these results could be a lower bound estimate of the impact of HTAs as some of the villages taken as controls might be targeted by an HTA created by either internal migrants or migrants living in other countries than France.

The contribution of HTAs to local public good provision also seems to translate into an increased household access to safe water through public fountains. Moreover, the share of households using a tap as their main source of water is found to be higher in the treated group, while the share of households using a well or a drilling is lower, suggesting an upgrade in water supply amenities. On the other hand, no significant impact is found regarding the percentage of households connected to electricity.

One of the most common problems with the difference-in-differences approach relies on the impossibility to directly test the parallel trend assumption on which it relies. In our case, a failure of this assumption would mean that our variables of interest, namely local public good provision and household access to local public goods, would have followed a different trend for the treated and control localities had there been no exposure to the treatment. To investigate the parallel trend assumption, we rely on the period preceding the treatment to test whether estimated changes in public good provision across treated and control localities were significantly different during the pre-treatment period. Due to lack of data on household access to water and electricity in the 1976 census, we are only able to implement this test for the three first measures of local public good availability, the number of schools, public fountains and health centers. Results are shown in the second panel of Tables 5 and 6 .

Whatever the specification (without commune trends in column (1a) or controlling for commune trends in column (1b)), the changes in the number of schools are not statistically different between treated and control villages over the 1976-1987 pre-treatment period. In other terms, school provision in the treated and control localities followed a virtually 
identical trend prior to the creation of the first HTAs, which increases the confidence in the identification assumption.

The same is not true for water amenities. The results suggest diverging pre-treatment trends in the provision of public fountains between treated and control villages, with treated villages recording a larger increase in the number of public fountains between 1976 and 1987. However, the size of the coefficient, 0.079, is much smaller than in the benchmark model, 1.029, which suggests that HTAs have contributed to exacerbate this diverging trend.

Finally, the test of parallel trend assumption for health centers suggests that, if any, the pre-treatment trend divergence was playing against the treated villages, as shown by the significantly negative coefficient in column (1b) of Table 6. Taking this result into account, the significantly positive coefficient of 0.267 obtained in the top of Table 6 suggests that, not only villages with an HTA are better off in terms of health amenities than the control villages, but that HTAs compensated for pre-treatment adverse trends in the treated villages.

Columns (2) to (4) of Tables 5 and 6 explore the timing of the treatment. Using the panel dimension of the data, we estimate separately the impact of earlier HTAs (created before 1998), and the impact of more recent HTAs (created after 1998). We first focus on HTAs created in France between 1987 and 1998, and look at their impact on the provision of local public goods in the Malian villages over the same period (column (2)), and over the following period, 1998-2009 (column (3)). In this setting, the treated group is composed of the 495 villages that were targeted by an HTA between 1987 and 1998 and the control group gathers the localities with no HTA over the whole period. 
Table 5: Benchmark Results - Part 1

\begin{tabular}{|c|c|c|c|c|c|c|}
\hline \multicolumn{7}{|c|}{ A. Difference in differences after the treatment occurred } \\
\hline \multirow{3}{*}{$\begin{array}{l}\text { Treatment: } \\
\text { Outcome period: }\end{array}$} & (1a) & (1b) & (2) & $(3)$ & \multirow{3}{*}{\multicolumn{2}{|c|}{$\begin{array}{c}(4) \\
\text { Recent HTA } \\
\text { 1998-2009 }\end{array}$}} \\
\hline & \multicolumn{2}{|c|}{ HTA } & \multicolumn{2}{|c|}{ Old HTA } & & \\
\hline & \multicolumn{2}{|c|}{$1987-2009$} & 1987-1998 & 1998-2009 & & \\
\hline SCHOOL & $\begin{array}{c}0.117^{* *} \\
(0.050)\end{array}$ & $\begin{array}{c}0.869^{* *} \\
(0.346)\end{array}$ & $\begin{array}{c}0.713^{* * *} \\
(0.240)\end{array}$ & $\begin{array}{l}-0.129 \\
(0.158)\end{array}$ & \multicolumn{2}{|c|}{$\begin{array}{l}0.568^{*} \\
(0.315)\end{array}$} \\
\hline WATER & $\begin{array}{c}0.294^{* * *} \\
(0.067)\end{array}$ & $\begin{array}{c}1.029^{* * *} \\
(0.374)\end{array}$ & $\begin{array}{c}0.427 \\
(0.300)\end{array}$ & $\begin{array}{r}2.177^{* *} \\
(1.043)\end{array}$ & \multicolumn{2}{|c|}{$\begin{array}{c}0.319 \\
(0.228)\end{array}$} \\
\hline HH_TAP & $\begin{array}{c}0.028^{* * *} \\
(0.005)\end{array}$ & $\begin{array}{c}0.044^{* * *} \\
(0.016)\end{array}$ & $\begin{array}{l}-0.003 \\
(0.005)\end{array}$ & $\begin{array}{l}0.045^{*} \\
(0.027)\end{array}$ & \multicolumn{2}{|c|}{$\begin{array}{c}0.033 \\
(0.020)\end{array}$} \\
\hline HH_WELL & $\begin{array}{c}-0.040^{* * *} \\
(0.011)\end{array}$ & $\begin{array}{l}-0.076^{*} \\
(0.043)\end{array}$ & $\begin{array}{c}0.014 \\
(0.065)\end{array}$ & $\begin{array}{l}-0.113^{*} \\
(0.059)\end{array}$ & \multicolumn{2}{|c|}{$\begin{array}{c}-0.124^{* * *} \\
(0.043)\end{array}$} \\
\hline HH_FOUNTAIN & $\begin{array}{c}0.019^{* * *} \\
(0.005)\end{array}$ & $\begin{array}{c}0.091^{* * *} \\
(0.022)\end{array}$ & $\begin{array}{c}0.034 \\
(0.029)\end{array}$ & $\begin{array}{c}0.094^{* *} \\
(0.042)\end{array}$ & \multicolumn{2}{|c|}{$\begin{array}{c}0.088^{* * *} \\
(0.033)\end{array}$} \\
\hline HH_ELEC & $\begin{array}{c}0.006^{* *} \\
(0.003)\end{array}$ & $\begin{array}{c}0.006 \\
(0.008)\end{array}$ & $\begin{array}{l}-0.002 \\
(0.004)\end{array}$ & $\begin{array}{c}0.020 \\
(0.017)\end{array}$ & \multicolumn{2}{|c|}{$\begin{array}{c}-0.010^{*} \\
(0.006)\end{array}$} \\
\hline Village fixed effects & Yes & Yes & Yes & Yes & \multicolumn{2}{|c|}{ Yes } \\
\hline Commune-level trends & No & Yes & Yes & Yes & \multicolumn{2}{|c|}{ Yes } \\
\hline Observations & 17,092 & 17,092 & 15,752 & 15,752 & \multicolumn{2}{|c|}{16,102} \\
\hline $\mathrm{Nb}$ of treated & 1,165 & 1,165 & 495 & 495 & \multicolumn{2}{|c|}{670} \\
\hline $\mathrm{Nb}$ of controls & 7,381 & 7,381 & 7,381 & 7,381 & \multicolumn{2}{|c|}{7,381} \\
\hline \multicolumn{7}{|c|}{ B. Testing the assumption of parallel trend before treatment } \\
\hline Outcome period: & \multicolumn{2}{|c|}{$1976-1987$} & \multicolumn{2}{|c|}{ 1976-1987 } & 1976-1987 & 1987-1998 \\
\hline SCHOOL & $\begin{array}{c}0.024 \\
(0.016)\end{array}$ & $\begin{array}{c}0.040 \\
(0.050)\end{array}$ & \multicolumn{2}{|c|}{$\begin{array}{l}-0.057 \\
(0.067)\end{array}$} & $\begin{array}{c}0.090 \\
(0.061)\end{array}$ & $\begin{array}{l}0.317^{*} \\
(0.193)\end{array}$ \\
\hline WATER & $\begin{array}{c}0.020^{* *} \\
(0.010)\end{array}$ & $\begin{array}{c}0.079^{* *} \\
(0.034)\end{array}$ & \multicolumn{2}{|c|}{$\begin{array}{l}-0.005 \\
(0.005)\end{array}$} & $\begin{array}{c}0.117^{* *} \\
(0.047)\end{array}$ & $\begin{array}{l}-0.010 \\
(0.084)\end{array}$ \\
\hline \multicolumn{5}{|l|}{ HH_TAP } & \multicolumn{2}{|r|}{$\begin{array}{c}0.011 \\
(0.007)\end{array}$} \\
\hline HH_WELL & & & & & & $\begin{array}{c}0.056 \\
(0.039)\end{array}$ \\
\hline HH_FOUNTAIN & & & & & & $\begin{array}{l}-0.014 \\
(0.021)\end{array}$ \\
\hline HH_ELEC & & & & & & $\begin{array}{l}0.009^{*} \\
(0.004)\end{array}$ \\
\hline Village fixed effects & Yes & Yes & \multicolumn{2}{|c|}{ Yes } & Yes & Yes \\
\hline Commune-level trends & No & Yes & \multicolumn{2}{|c|}{ Yes } & Yes & Yes \\
\hline Observations & 17,092 & 17,092 & \multicolumn{2}{|c|}{15,752} & 16,102 & 16,102 \\
\hline $\mathrm{Nb}$ of treated & 1,165 & 1,165 & \multirow{2}{*}{\multicolumn{2}{|c|}{$\begin{array}{c}495 \\
7,381\end{array}$}} & 670 & 670 \\
\hline $\mathrm{Nb}$ of controls & 7,381 & 7,381 & & & 7,381 & 7,381 \\
\hline
\end{tabular}


Table 6: Benchmark Results - Part 2

\begin{tabular}{|c|c|c|c|c|c|}
\hline \multicolumn{6}{|c|}{ A. Difference in differences after the treatment occurred } \\
\hline \multirow{3}{*}{$\begin{array}{l}\text { Treatment: } \\
\text { Outcome period: } \\
\text { HEALTH }\end{array}$} & \multirow{2}{*}{\multicolumn{2}{|c|}{$\begin{array}{c}\text { HTA } \\
1987-2009\end{array}$}} & \multicolumn{2}{|c|}{ Old HTA } & Recent HTA \\
\hline & & & $1987-1998$ & 1998-2009 & 1998-2009 \\
\hline & $\begin{array}{c}0.040^{* * *} \\
(0.014)\end{array}$ & $\begin{array}{c}0.267^{* * *} \\
(0.061)\end{array}$ & $\begin{array}{c}0.783^{* * *} \\
(0.146)\end{array}$ & $\begin{array}{c}-0.470^{* * *} \\
(0.145)\end{array}$ & $\begin{array}{c}0.021 \\
(0.084)\end{array}$ \\
\hline HOSP & & & & $\begin{array}{c}0.035 \\
(0.033)\end{array}$ & $\begin{array}{c}0.021 \\
(0.015)\end{array}$ \\
\hline CLINICS & & & & $\begin{array}{l}-0.032 \\
(0.020)\end{array}$ & $\begin{array}{l}-0.000 \\
(0.018)\end{array}$ \\
\hline DISPENS & & & & $\begin{array}{c}-0.279^{* *} \\
(0.110)\end{array}$ & $\begin{array}{c}-0.115^{* *} \\
(0.050)\end{array}$ \\
\hline MATER & & & & $\begin{array}{c}-0.321^{* * *} \\
(0.100)\end{array}$ & $\begin{array}{c}-0.156^{* * *} \\
(0.060)\end{array}$ \\
\hline CSCOM & & & & $\begin{array}{c}0.160^{* *} \\
(0.081)\end{array}$ & $\begin{array}{c}0.249^{* * *} \\
(0.067)\end{array}$ \\
\hline Village fixed effects & Yes & Yes & Yes & Yes & Yes \\
\hline Commune-level trends & No & Yes & Yes & Yes & Yes \\
\hline Observations & 17,092 & 17,092 & 15,752 & 15,752 & 16,102 \\
\hline $\mathrm{Nb}$ of treated & 1,165 & 1,165 & 495 & 495 & 670 \\
\hline $\mathrm{Nb}$ of controls & 7,381 & 7,381 & 7,381 & 7,381 & 7,381 \\
\hline
\end{tabular}

B. Testing the assumption of parallel trend before treatment

\begin{tabular}{|c|c|c|c|c|c|c|}
\hline Outcome period: & \multicolumn{2}{|c|}{$1976-1987$} & \multicolumn{2}{|c|}{$1976-1987$} & \multirow{2}{*}{$\begin{array}{c}1976-1987 \\
-0.018 \\
(0.032)\end{array}$} & \multirow{2}{*}{$\begin{array}{c}1987-1998 \\
0.214^{* *} \\
(0.100)\end{array}$} \\
\hline HEALTH & $\begin{array}{c}0.007 \\
(0.009)\end{array}$ & $\begin{array}{c}-0.061^{*} \\
(0.037)\end{array}$ & & & & \\
\hline Village fixed effects & Yes & Yes & \multicolumn{2}{|c|}{ Yes } & Yes & Yes \\
\hline Commune-level trends & No & Yes & \multicolumn{2}{|c|}{ Yes } & Yes & Yes \\
\hline Observations & 17,092 & 17,092 & \multicolumn{2}{|c|}{15,752} & 16,102 & 16,102 \\
\hline $\mathrm{Nb}$ of treated & 1,165 & 1,165 & 495 & 495 & \multicolumn{2}{|c|}{670} \\
\hline $\mathrm{Nb}$ of controls & 7,381 & 7,381 & 7,381 & 7,381 & \multicolumn{2}{|c|}{7,381} \\
\hline
\end{tabular}

Robust standard errors in parentheses, clustered at the village level. ${ }^{* * *} \mathrm{p}<0.01,{ }^{* *} \mathrm{p}<0.05,{ }^{*} \mathrm{p}<0.1$.

Each coefficient corresponds to a different estimation, the dependant variable appearing in rows.

Column (1a) presents standard double-differences, while Columns (1b), (2), (3) and (4) introduce commune-level time trends.

In all columns, the control group gathers the villages without HTA. In Columns (1a) and (1b), the treated villages are those with an HTA (whatever its date of creation). In Columns (2) and (3), the treated group is composed of the villages with an HTA created between 1987 and 1998, while in Column (4) the treated villages are those with an HTA created after 1998.

In both columns we control for the communes trends. Tables 5 and 6 illustrate the evolution in the actions undertaken by early HTAs. They concentrated their actions on building schools and health amenities in the first decade (column (2)). Then, between 1998 and 2009, their actions switched and focused on water supply as reflected by the large positive coefficient for water, but also by the positive impact on the share of households 
using a tap or a fountain as their main source of water. During the 1998-2009 period, the impact of early HTAs on the supply of schools is no longer significant. It even becomes negative $(-0.470)$ for health amenities. However, this negative overall coefficient hides contrasted trends which become apparent when health infrastructures are further disaggregated. Indeed, during the 1998-2009 period, the development of CSCOM (centres de santé communautaires) have substituted for dispensaries and maternities. This switch has been even more pronounced in the treated villages, as illustrated by the coefficients associated with the numbers of dispensaries, maternities and CSCOM in column (3) of Table 6 .

Finally, the results shown in the bottom part of Tables 5 and 6 support the assumption that pre-treatment trends were similar across treated and control villages regarding schools and public fountains. Regarding health centers, the divergence in pre-treatment trends was, again, playing against the treated villages (negative coefficient).

Symmetrically, we investigate in column (4) the impact of HTAs created during the following decade, 1998-2009, on local public good provision. In this setting, the treated group is composed of 670 villages with an HTA created after 1998, that we compare to the 7,381 villages with no HTA over the whole period (the control group). The 60 villages with an HTA created before 1987, as well as the 495 villages with an HTA created between 1987 and 1998, are excluded from the sample. The double difference is implemented over the 1998-2009 period, while we will investigate the parallel trend assumption both over the 1976-1987 and over the 1987-1998 periods.

The results of the double difference suggest a weaker impact of recent HTAs on the provision of public goods. The coefficient associated with recent HTAs in the equation for the number of public fountains is no longer significant. Neither is the coefficient associated with recent HTAs when the number of health amenities is used as the outcome variable. However, when this outcome is disaggregated, we observe that villages with a recent HTA have also experienced a more rapid expansion of CSCOM (at the expanse of maternities and dispensaries) than control villages. Finally, recent HTAs seem to have had a positive 
impact on the number of schools over the 1998-2009 period, a result that should be taken with caution given that the bottom part of the table suggests diverging pre-treatment trends for the treated and control villages.

Overall, these results suggest that over the 1998-2009 period the action of both early and late HTAs has been associated with an upgrade in the supply of water amenities (increase in the share of households using public fountains as a source of water, against the use of wells and drilling) and a switch from dispensaries and maternities to CSCOM. This switch induces a non significant difference between treated and control villages when we consider the aggregate number of health infrastructures. However, the placebo test presented at the bottom of the table does not support the parallel trend assumption, casting some doubts on the results for the total number of health centers but also potentially for the different sub-categories of health infrastructures.

The investigation of the provision of local public goods in villages targeted by HTAs over two different subperiods suggests that the activity of HTAs has changed over time. First focusing on schools and water amenities, they then concentrated their actions on health infrastructures, supporting a switch from financing maternities and dispensaries to financing CSCOM at the end of the nineties.

\section{$5 \quad$ Robustness checks}

In the difference-in-differences approach presented above, we control both for time-unvarying village fixed-effects and for time-varying unobservable characteristics at the communelevel. However, it may well be the case that time-varying village characteristics explain both the propensity to have an HTA and the supply of public goods in the Malian villages. In what follows, we investigate to what extent the impact of HTAs may be considered as a causal impact or rather as reflecting specific characteristics of the treated villages. 


\subsection{Controlling for observable confounding factors}

As shown in Table 4, treated and control villages differ in their size, in their ethnolinguistic fragmentation, in the share of the labor force working in the agricultural sector and in the climatic conditions they face. They are also very different in terms of migration intensity, measured both through past migration (as suggested by the share of the population with a past migration experience in France) and through current migration (as suggested by the share of the population having migrated to France in the last five years). Table 7 explores the impact of HTAs on public good provision after introducing those additional control variables in the benchmark estimations (namely, the size of the population in logarithm, the ethno-linguistic fragmentation, the share of the labor force working in the primary sector, and the average rainfalls level and shock over the ten preceding years). Overall, the results are very similar to those of Tables 5 and 6 .

In column (1), we estimate the difference-in-differences in the change of public good provision over the 1987-2009 period. At that stage, we cannot introduce the measure of return migration intensity since it is not available in the data before 1998. The results are virtually the same as those of column (1b) in Tables 5 and 6 . The second column explores the impact of old HTAs on the change in public good provision over the 1987-1998 period. Migration intensity cannot be included here neither. However, controlling for the size of the population, ethno-linguistic fragmentation, the size of the primary sector and rainfalls leads to results which are similar in all points to those of column (2) in Tables 5 and 6 . In columns (3a) to (4b) we then explore the impact of old and recent HTAs on the provision of public goods during the recent decade, 1998-2009, controlling or not for the share of return migrants in the villages. Again, controlling for those covariates does not alter our conclusions. In Annex A we present the complete results of the seven estimations presented in column (1) of Table $7^{11}$.

\footnotetext{
${ }^{11}$ The coefficients associated with the different covariates are consistent with the literature on the determinants of local public good provision. In particular, the number of infrastructures is positively correlated with the size of the population and negatively with ethno-linguistic fragmentation. When performing the estimations over the recent period (1998-2009) as in columns (3b) and (4b), we can also observe the correlations between the intensity of return migration from France and the provision of
} 
local public goods. The coefficient associated with return migration from France is not systematically significant. When it is, its value is positive (results available upon request). 
Table 7: Adding time-varying covariates

\begin{tabular}{|c|c|c|c|c|c|c|}
\hline & (1) & $(2)$ & (3a) & $(3 \mathrm{~b})$ & (4a) & $(4 \mathrm{~b})$ \\
\hline Treatment: & HTA & Old HTA & \multicolumn{2}{|c|}{ Old HTA } & \multicolumn{2}{|c|}{ Recent HTA } \\
\hline Outcome period: & 1987-2009 & 1987-1998 & 1998 & 2009 & 1998 & 2009 \\
\hline SCHOOL & $\begin{array}{c}0.868^{* *} \\
(0.344)\end{array}$ & $\begin{array}{c}0.718^{* * *} \\
(0.240)\end{array}$ & $\begin{array}{l}-0.112 \\
(0.159)\end{array}$ & $\begin{array}{c}-0.108 \\
(0.160)\end{array}$ & $\begin{array}{l}0.553^{*} \\
(0.315)\end{array}$ & $\begin{array}{l}0.549^{*} \\
(0.316)\end{array}$ \\
\hline WATER & $\begin{array}{c}1.024^{* * *} \\
(0.374)\end{array}$ & $\begin{array}{c}0.432 \\
(0.301)\end{array}$ & $\begin{array}{c}2.174^{* *} \\
(1.043)\end{array}$ & $\begin{array}{c}2.181^{* *} \\
(1.042)\end{array}$ & $\begin{array}{c}0.318 \\
(0.226)\end{array}$ & $\begin{array}{c}0.313 \\
(0.225)\end{array}$ \\
\hline HH_TAP & $\begin{array}{c}0.044^{* * *} \\
(0.016)\end{array}$ & $\begin{array}{l}-0.002 \\
(0.005)\end{array}$ & $\begin{array}{l}0.045^{*} \\
(0.027)\end{array}$ & $\begin{array}{c}0.044 \\
(0.027)\end{array}$ & $\begin{array}{l}0.033^{*} \\
(0.020)\end{array}$ & $\begin{array}{l}0.034^{*} \\
(0.020)\end{array}$ \\
\hline HH_WELL & $\begin{array}{c}-0.078^{*} \\
(0.043)\end{array}$ & $\begin{array}{c}0.015 \\
(0.065)\end{array}$ & $\begin{array}{c}-0.118^{* *} \\
(0.059)\end{array}$ & $\begin{array}{c}-0.118^{* *} \\
(0.059)\end{array}$ & $\begin{array}{c}-0.124^{* * *} \\
(0.043)\end{array}$ & $\begin{array}{c}-0.123^{* * *} \\
(0.043)\end{array}$ \\
\hline HH_FOUNTAIN & $\begin{array}{c}0.091^{* * *} \\
(0.022)\end{array}$ & $\begin{array}{c}0.034 \\
(0.029)\end{array}$ & $\begin{array}{c}0.094^{* *} \\
(0.042)\end{array}$ & $\begin{array}{c}0.095^{* *} \\
(0.042)\end{array}$ & $\begin{array}{c}0.088^{* * *} \\
(0.033)\end{array}$ & $\begin{array}{c}0.087^{* * *} \\
(0.032)\end{array}$ \\
\hline HH_ELEC & $\begin{array}{c}0.006 \\
(0.008)\end{array}$ & $\begin{array}{l}-0.002 \\
(0.004)\end{array}$ & $\begin{array}{c}0.021 \\
(0.017)\end{array}$ & $\begin{array}{c}0.021 \\
(0.017)\end{array}$ & $\begin{array}{l}-0.009 \\
(0.006)\end{array}$ & $\begin{array}{c}-0.009^{*} \\
(0.006)\end{array}$ \\
\hline HEALTH & $\begin{array}{c}0.267^{* * *} \\
(0.060)\end{array}$ & $\begin{array}{c}0.785^{* * *} \\
(0.147)\end{array}$ & $\begin{array}{c}-0.463^{* * *} \\
(0.146)\end{array}$ & $\begin{array}{c}-0.460^{* * *} \\
(0.145)\end{array}$ & $\begin{array}{c}0.018 \\
(0.084)\end{array}$ & $\begin{array}{c}0.017 \\
(0.084)\end{array}$ \\
\hline HOSP & & & $\begin{array}{c}0.035 \\
(0.033)\end{array}$ & $\begin{array}{c}0.035 \\
(0.034)\end{array}$ & $\begin{array}{c}0.021 \\
(0.015)\end{array}$ & $\begin{array}{c}0.021 \\
(0.015)\end{array}$ \\
\hline CLINICS & & & $\begin{array}{l}-0.031 \\
(0.020)\end{array}$ & $\begin{array}{l}-0.031 \\
(0.019)\end{array}$ & $\begin{array}{l}-0.001 \\
(0.018)\end{array}$ & $\begin{array}{l}-0.001 \\
(0.018)\end{array}$ \\
\hline DISPENS & & & $\begin{array}{c}-0.278^{* *} \\
(0.110)\end{array}$ & $\begin{array}{c}-0.276^{* *} \\
(0.110)\end{array}$ & $\begin{array}{c}-0.115^{* *} \\
(0.050)\end{array}$ & $\begin{array}{c}-0.117^{* *} \\
(0.050)\end{array}$ \\
\hline MATER & & & $\begin{array}{c}-0.318^{* * *} \\
(0.100)\end{array}$ & $\begin{array}{c}-0.316^{* * *} \\
(0.100)\end{array}$ & $\begin{array}{c}-0.157^{* * *} \\
(0.060)\end{array}$ & $\begin{array}{c}-0.159^{* * *} \\
(0.060)\end{array}$ \\
\hline CSCOM & & & $\begin{array}{c}0.163^{* *} \\
(0.081)\end{array}$ & $\begin{array}{c}0.162^{* *} \\
(0.082)\end{array}$ & $\begin{array}{c}0.248^{* * *} \\
(0.066)\end{array}$ & $\begin{array}{c}0.250^{* * *} \\
(0.066)\end{array}$ \\
\hline Time-varying covariates & Yes & Yes & Yes & Yes & Yes & Yes \\
\hline \% Return migrants from France & No & No & No & Yes & No & Yes \\
\hline Village fixed effects & Yes & Yes & Yes & Yes & Yes & Yes \\
\hline Commune-level trends & Yes & Yes & Yes & Yes & Yes & Yes \\
\hline Observations & 17,091 & 15,739 & 15,738 & 15,738 & 16,088 & 16,088 \\
\hline $\mathrm{Nb}$ of treated & 1,165 & 1,165 & 495 & 495 & 670 & 670 \\
\hline $\mathrm{Nb}$ of controls & 7,381 & 7,381 & 7,368 & 7,368 & 7,368 & 7,368 \\
\hline
\end{tabular}

Robust standard errors in parentheses, clustered at the village level. ${ }^{* * *} \mathrm{p}<0.01,{ }^{* *} \mathrm{p}<0.05,{ }^{*} \mathrm{p}<0.1$.

Each coefficient corresponds to a different estimation, the dependant variable appearing in rows.

In all columns, the control group gathers the villages without HTA. In Column (1), the treated villages are those with an HTA (whatever its date of creation). In Columns (2), (3a) and (3b), the treated group is composed of the villages with an HTA created between 1987 and 1998, while in Column (4a) and (4b) the treated villages are those with an HTA created after 1998.

Time-varying covariates include: population (in logarithm), index of ethnolinguistic fractionnalization, annual rainfall average over $[t, t-1]$, annual rainfall shock over $[t, t-1]$, and share of the active population working in the primary sector.

The number of return migrants coming back from France over the total population of the village is also controlled for in Columns (3b) and (4b). 


\section{$5.2 \quad$ Selection issue}

In what follows, we exploit the panel dimension of the data and the fact that some villages have been treated since 1987, while others are only treated from 1998. This timing of the treatment makes it possible to compare villages with an old HTA with villages with a recent HTA. By comparing them, we thus explore the differences between two groups which are similar in more dimensions than villages with an HTA over the whole period and villages with no HTA at all. In particular, we assume that time-varying unobservable characteristics, that cannot be directly controlled for, are closer between these villages which are all to be treated at one point in time.

Moreover, as shown in Table 8, the villages benefitting from an early treatment and those benefitting from a more recent treatment are not significantly different regarding migration intensity. ${ }^{12}$ This point is crucial since we may suspect that the impact of HTAs highlighted above reflects higher migration intensity rather than the action of HTAs per se. ${ }^{13}$

In Table 9, we run difference-in-differences estimations over the 1987-1998 period, considering the villages with an HTA registered between 1987 and 1998 as treated and the villages targeted by an HTA after 1998 as non-treated. This strategy reduces the potential selection-into-treatment issue. Column (1) presents the estimated differences in terms of local public good provision between these treated and control villages over the 1987-1998 period (i.e., when the villages with an old HTA were already treated while the villages with a recent HTA were not treated yet). In this specification, the number of schools and of health amenities appear to differ significantly between treated and control villages, the treated group being better endowed. This first result suggests that, even when comparing treated villages with soon-to-be treated villages, the treatment is associated with a significantly larger local public good endowment.

\footnotetext{
${ }^{12}$ As well as ethnic fragmentation and rainfall shocks.

${ }^{13}$ The comparative descriptive statistics on local public good provision between villages treated by old and recent HTAs are presented in Annex B.
} 


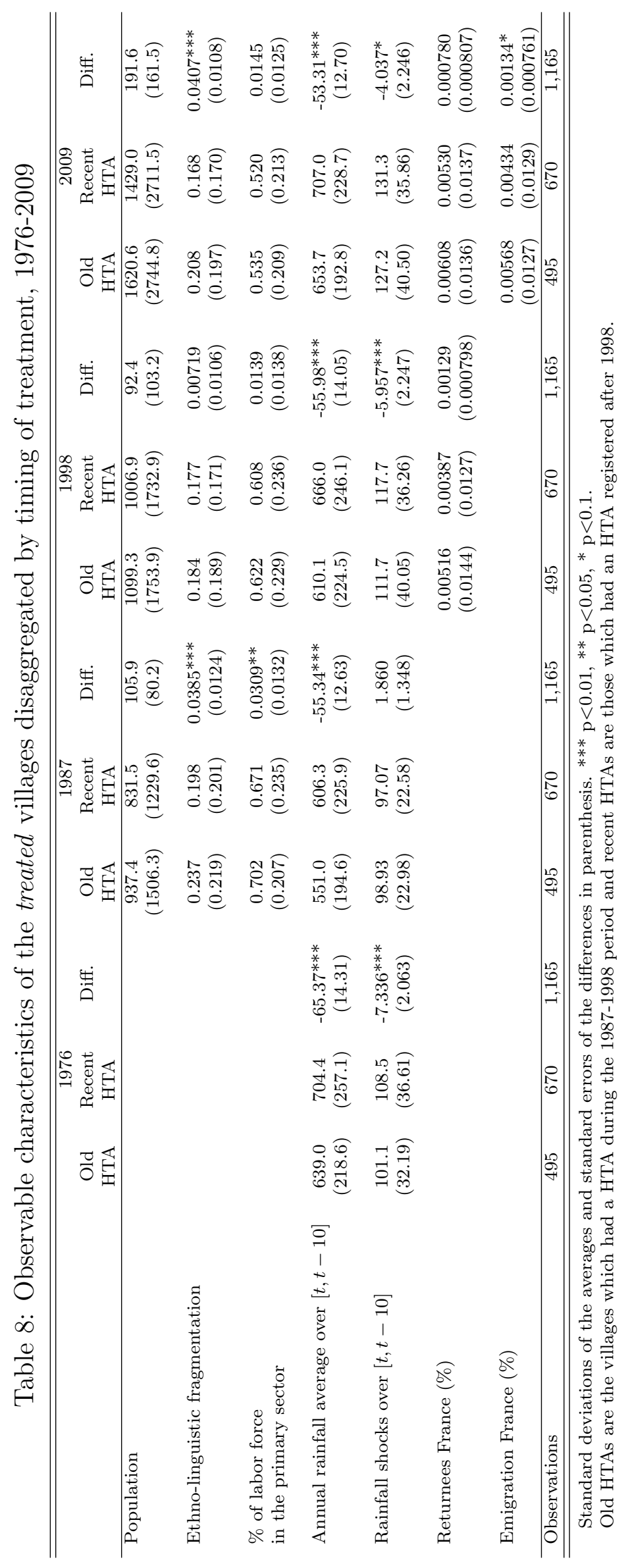


In column (2), we re-iterate the same double-difference estimation over the preceding period, 1976-1987, as a placebo test. It appears here that the number of schools in the treated group was already higher than in the control group before the treatment occurred. However, the size of the two coefficients suggests that the creation of HTAs during the following period exacerbated this already existing diverging trends in terms of school endowment. Moreover, the estimated coefficient associated with the treatment dummy in the health equation is not significant in column (2). Thus, while the number of health equipments is found to be significantly larger in the treated group in column (1), the pre-treatment trends regarding health equipments estimated in column (2) are not significantly different between treated and control villages.

Finally, column (3) presents the same estimations as column (1) introducing our vector of time-varying control variables, to take into account observable trends that may simultaneously affect the treatment status and the provision of local public goods. Unfortunately we are not able to control for migration intensity (as proxied by the share of return migrants) since this variable is only available for 1998 and 2009. In this specification, the size and significance of the estimated coefficients are very close to those obtained in column (1). Taken together, the results of these three columns suggest that when we compare similar villages, which are all going to be treated at one point in time, during the period when only part of them are treated, significant differences in terms of local public good provision already appear, notably for the number of schools and health infrastructures. This provides us with more confidence over the fact that our benchmark results are not completely driven by selection issues. 
Table 9: Old vs. recent HTAs

\begin{tabular}{lccc}
\hline \hline & $(1)$ & $(2)$ & $(3)$ \\
Outcome period: & $1987-1998$ & $1976-1987$ & $1987-1998$ \\
\hline SCHOOL & $0.503^{* * *}$ & $0.214^{*}$ & $0.511^{* * *}$ \\
& $(0.160)$ & $(0.111)$ & $(0.157)$ \\
WATER & 0.633 & -0.068 & 0.633 \\
& $(0.593)$ & $(0.053)$ & $(0.588)$ \\
HH_TAP & 0.029 & & \\
& $(0.020)$ & & 0.029 \\
HH_WELL & -0.039 & & $-0.020)$ \\
& $(0.041)$ & & -0.038 \\
HH_FOUNTAIN & -0.001 & & $-0.041)$ \\
& $(0.011)$ & & $(0.011)$ \\
HH_ELEC & & & \\
& -0.003 & & -0.002 \\
HEALTH & $(0.003)$ & & $(0.003)$ \\
& & & \\
Village fixed effects & $(0.182)$ & $(0.103)$ & $(0.181)$ \\
Yemmune-level trends & Yes & Yes & Yes \\
Time-varying covariates & No & No & Yes \\
Observations & 2330 & 2330 & 2330 \\
Nb of treated & 495 & 495 & 495 \\
Nb of controls & 670 & 670 & 670 \\
\hline \hline
\end{tabular}

Robust standard errors in parentheses, clustered at the village level. ${ }^{* * *} \mathrm{p}<0.01$, $* * \mathrm{p}<0.05, * \mathrm{p}<0.1$.

Each coefficient corresponds to a different estimation, the dependant variable appearing in rows.

The treated group gathers the villages with an HTA created between 1987 and 1998, while villages with an HTA created after 1998 compose the control group.

\section{Conclusion}

In this paper we question the impact of migrants HTAs registered in France on the provision of public goods in Mali. Malian migrants in France gather in HTAs to send collective transfers to their locality of origin and contribute to local development. Almost one fifth of the Malian villages is targeted by HTA aiming at participating to the provision of public goods, such as schools or health facilities. However, the impact of these HTAs on the local development of Malian villages is not straightforward since HTAs' activity 
may crowd out public finance, be less effective than local intervention, and affect local governance habits.

We rely on a difference-in-differences approach to assess the differences, in terms of local public good provision, between the Malian villages targeted by an HTA over the 1987-2009 period and the villages with no HTA. We find that targeted villages exhibit a significantly higher average level of public goods over the 1987-2009 period than villages with no HTA. This significant difference is observed for schools and health centers as well as water amenities, the difference between treated and control localities in terms of water infrastructures being mainly driven by the second period of analysis (1998-2009). These results are robust to the introduction of time-varying variables in the estimations.

Overall, the empirical evidence presented in this paper shows that Malian villages targeted by an HTA registered in France are significantly better endowed in terms of local public goods than the others. Despite the large scale public investments in social services implemented since the nineties, villages with no HTA did not manage to catch up with those benefiting from these collective transfers. Our quantitative assessment of the impact of Malian HTAs paves the way for further research to understand the channels through which collective transfers affect local public good provision, and in particular to identify the political economy mechanisms at play since HTAs are non-state agents interfering in the process of public good provision.

The impact of HTAs may first be explained by the important ability of migrants to collect funds (either because their private incomes are high enough to finance collective project, or because they were able to mobilize French public funds through the so-called co-development initiatives which expanded in the nineties, HTAs being one of the main actors of these official development assistance projects). Second, the positive impact of HTAs on public good provision may stem from higher effectiveness and better choices in terms of local development. HTAs may notably contribute to improve local governance by asking for more accountability of the local elite and transparency of public affairs, thus reducing the capture of public funds. 
Finally, this paper opens the question of the impact of HTAs on intra-locality inequality. The presence of HTAs and their involvement in the provision of public goods may exacerbate existing diverging interests, especially if the intended beneficiaries do not have much voice in the selection and oversight of the funded development projects. Inversely, HTAs may reduce the unequal access of public goods by financing investment in areas lagging behind. All these research questions are over the scope of this paper and call for innovative research frames. 


\section{References}

Aparicio, Francisco Javier and Covadonga Meseguer. 2012. "Collective Remittances and the State: The $3 \times 1$ Program in Mexican Municipalities." World Development 40 (1):206-222.

Beauchemin, Cris and Bruno Schoumaker. 2009. "Are migrant associations actors in local development? A national event-history analysis in rural Burkina Faso." World development 37 (12):1897-1913.

Bernard, Claire, Lisa Chauvet, Flore Gubert, Marion Mercier, and Sandrine MespléSomps. 2013. "La dynamique associative des Maliens de l'extérieur: enseignements tirés de deux dispositifs d'enquête originaux." DIAL mimeo .

Charef, Mohamed and Patrick Gonin. 2005. Emigrés - immigrés dans le développement local. Sud contact, Agadir.

Daum, Christophe. 1995. "Les migrants, partenaires de la coopération internationale: le cas des Maliens de France." Tech. rep., OECD Publishing.

1998. Les associations de Maliens en France: migrations, développement et citoyenneté. KARTHALA Editions.

Gauvrit, Lisa and Goulven Le Bahers. 2004. "Pratiques associatives des migrants pour le développement de leur pays d'origine: le cas des migrants maliens de France originaires de la Région de Kayes." MAE-FSP codéveloppement Mali .

Grabel, Ilene. 2008. "The Political Economy of Remittances: What do we know? What do we need to know?" PERI Working Papers .

Manchuelle, François. 1997. Willing migrants: Soninke labor diasporas, 1848-1960. Ohio University Press Athens. 
Quiminal, Catherine. 1991. Gens d'ici et d'ailleurs, migrations soninkes et transformations villageoises. Christian Bourgeois, Paris.

Ratha, Dilip and Ani Silwal. 2012. "Remittance flows in 2011: an update." Tech. Rep. 18, Migration and Remittances Unit, World Bank. 
Annex A: Adding time-varying covariates - Detailed results

\begin{tabular}{|c|c|c|c|c|c|c|c|}
\hline & (1) & $(2)$ & (3) & (4) & (5) & (6) & (7) \\
\hline VARIABLES & SCHOOL & WATER & HH_TAP & HH_WELL & HH_FOUNTAIN & HH_ELEC & HEALTH \\
\hline \multirow[t]{2}{*}{ HTA } & $0.868^{* *}$ & $1.024^{* * *}$ & $0.0436^{* * *}$ & $-0.0781^{*}$ & $0.0905^{* * *}$ & 0.00585 & $0.267 * * *$ \\
\hline & $(0.344)$ & $(0.374)$ & $(0.0164)$ & $(0.0430)$ & $(0.0218)$ & $(0.00777)$ & $(0.0602)$ \\
\hline Population & $0.209 * * *$ & 0.0551 & -0.00178 & 0.00196 & -0.00114 & 0.000420 & $0.0416^{* * *}$ \\
\hline (in logarithm) & $(0.0528)$ & $(0.0474)$ & $(0.00264)$ & $(0.00695)$ & $(0.00273)$ & $(0.00171)$ & $(0.00940)$ \\
\hline Ethno-linguistic & $-0.281^{* * *}$ & -0.0893 & 0.00342 & $-0.105^{* * *}$ & 0.00757 & $0.00928^{*}$ & 0.00130 \\
\hline fragmentation & $(0.104)$ & $(0.0935)$ & $(0.00624)$ & $(0.0229)$ & $(0.00970)$ & $(0.00477)$ & $(0.0253)$ \\
\hline$\%$ of the labor force & -0.110 & $-0.176^{* * *}$ & $-0.0135 * * *$ & 0.0226 & -0.00986 & -0.00197 & $-0.0594^{* * *}$ \\
\hline in the primary sector & $(0.0733)$ & $(0.0600)$ & $(0.00501)$ & $(0.0142)$ & $(0.00678)$ & $(0.00295)$ & $(0.0179)$ \\
\hline Annual rainfall average & $-0.00163^{*}$ & -0.000311 & 0.000137 & 0.000100 & $-0.000504^{* * *}$ & $7.38 \mathrm{e}-05$ & $0.000799 * *$ \\
\hline over $[t, t-1]$ & $(0.000982)$ & $(0.00126)$ & $(0.000136)$ & $(0.000302)$ & $(0.000168)$ & $(5.44 \mathrm{e}-05)$ & $(0.000404)$ \\
\hline Annual rainfall shock & 0.00209 & 0.000825 & -0.000115 & -0.000301 & 0.000159 & $-6.98 \mathrm{e}-05$ & -0.000284 \\
\hline over $[t, t-1]$ & $(0.00201)$ & $(0.00123)$ & $(9.34 \mathrm{e}-05)$ & $(0.000273)$ & $(0.000127)$ & $(4.68 \mathrm{e}-05)$ & $(0.000420)$ \\
\hline Village fixed effects & Yes & Yes & Yes & Yes & Yes & Yes & Yes \\
\hline Commune-level time trends & Yes & Yes & Yes & Yes & Yes & Yes & Yes \\
\hline Observations & 17,091 & 17,091 & 17,091 & 17,091 & 17,091 & 17,091 & 17,091 \\
\hline $\mathrm{Nb}$ of treated & 1,165 & $1,1651,165$ & 1,165 & 1,165 & 1,165 & 1,165 & \\
\hline $\mathrm{Nb}$ of controls & 7,381 & 7,381 & 7,381 & 7,381 & 7,381 & 7,381 & 7,381 \\
\hline R-squared & 0.412 & 0.238 & 0.179 & 0.215 & 0.269 & 0.164 & 0.356 \\
\hline
\end{tabular}

Robust standard errors in parentheses, clustered at the village level. $* * * \mathrm{p}<0.01,{ }^{* *} \mathrm{p}<0.05, * \mathrm{p}<0.1$.

In all columns, the control group gathers the villages without HTA and the treated villages are those with an HTA (whatever its date of creation). 


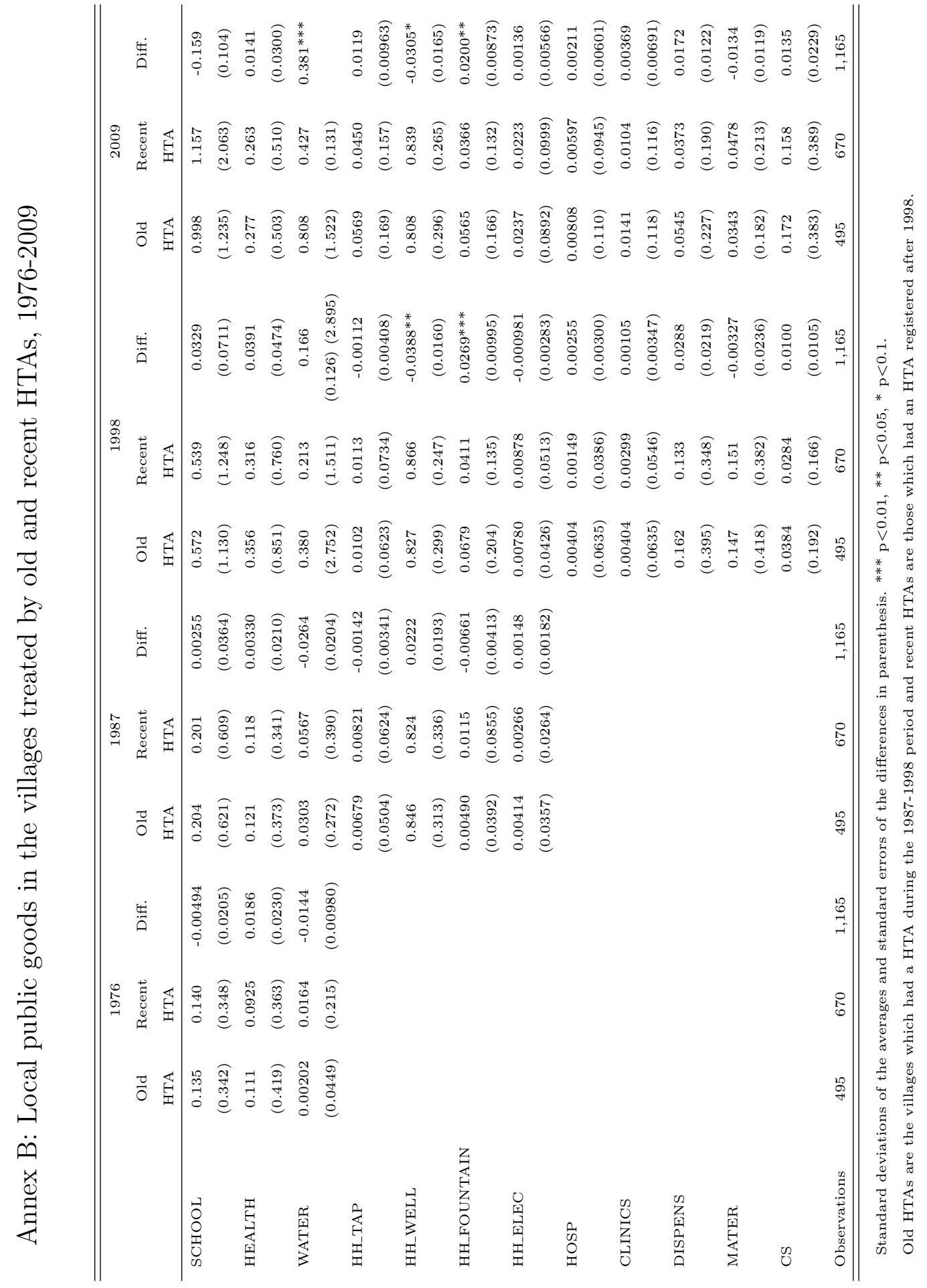

